\title{
CLOUD COMPUTING DAN DAMPAKNYA TERHADAP BISNIS
}

\author{
James Tandy; Siswono \\ Information Systems Department, School of Information Systems, Binus University \\ Jl. K.H. Syahdan No. 9, Palmerah, Jakarta Barat 11480 \\ jamestandysup@gmail.com; sisbinus@yahoo.com
}

\begin{abstract}
The purpose of this paper is to provide an overview of cloud computing and its development as well as the advantages and disadvantages of cloud computing implementation at some companies. Some literature studies from journals, textbooks and internet sources are discussed. Based on these searches it is known that the cloud computing as a technology that utilizes internet services uses a central server to the virtual nature of data and application maintenance purposes. The existence of Cloud Computing itself causes a change in the way the technology information system works at an company. Security and data storage systems have become important factors for the company.Cloud Computing technology provides a great advantage for most enterprises.
\end{abstract}

Keywords: cloud computing, business

\begin{abstract}
ABSTRAK
Tujuan dari penulisan paper ini adalah memberikan gambaran mengenai pengertian cloud computing dan perkembangannya serta keuntungan dan kerugian dari perusahaan yang memanfaatkan teknologi teknologi Cloud Computing. Metode yang dipergunakan dalam penulisan paper ini menggunakan pendekatan studi literatur melalui penelusuran terhadap jurnal, buku teks dan internet. Berdasarkan penelusuran tersebut diketahui bahwa Cloud Computing sebagai teknologi yang memanfaatkan layanan internet menggunakan pusat server yang bersifat virtual dengan tujuan pemeliharaan data dan aplikasi. Keberadaan Cloud Computing sendiri telah menimbulkan perubahan dalam cara kerja sistem teknologi informasi pada sebuah perusahaan. Sistem keamanan dan penyimpanan data menjadi hal yang penting bagi perusahaan. Teknologi Cloud Computing telah memberikan keuntungan yang besar bagi kebanyakan perusahaan.
\end{abstract}

Kata kunci: cloud computing, bisnis 


\title{
PENDAHULUAN
}

Perkembangan bisnis pada masa kini sangat pesat, banyak perusahaan yang saling bersaing untuk menjadi yang terbaik dalam bidangnya. Dalam persaingan tersebut, perusahaan harus mencari cara untuk dapat memberikan pelayanan yang lebih baik untuk meningkatkan minat masyarakat terhadap produk/jasa perusahaan tersebut. Tetapi peningkatan pelayanan dan pengembangan pada perusahaan selalu tidak lepas dari tingginya biaya yang harus dikeluarkan. Fenomena ini membuat beberapa perusahaan menjadi terhambat untuk meningkatkan kinerjanya.

Pada sisi yang lain, perkembangan teknologi informasi pada saat ini sudah mulai menjadi konsumsi banyak perusahaan. Dampak positif yang diberikan oleh teknologi informasi kini membuat perusahaan mulai bergantung pada teknologi infomasi dan meyakini bahwa teknologi informasi merupakan salah satu jawaban bagi perkembangan bisnis mereka. Namun nyatanya tidak semua perusahaan dapat berkembang dengan menggunakan teknologi informasi, pemakaian yang kurang efektif dan dampak yang sedikit terhadap perusahaan.

\begin{abstract}
Dengan semakin berkembangnya bisnis mereka menyebabkan penggunaan media penyimpanan dan keamanan menjadi faktor yang mengharuskan perusahaan untuk mengembangkannya lebih jauh. Biaya yang harus dikeluarkan untuk mengembangkan media penyimpanan dan keamanan sangatlah besar terlebih untuk perusahaan yang berskala besar.
\end{abstract}

Cloud Computing merupakan salah satu alternatif bagi perusahaan untuk menekan biaya-biaya yang menyangkut hal-hal tersebut.

\section{METODE}

Pendekatan yang dipergunakan dalam penulisan artikel ini berupa studi literatur yang diharapkan dapat memberikan wawasan kepada para pembaca dan secara khusus kepada pelaku bisnis terkait dengan pemanfaatan Cloud Computing dalam melaksanakan kegiatan bisnis.

\section{HASIL DAN PEMBAHASAN}

\section{Pengertian Cloud Computing dan Perkembangannya}

Al Azhar (2013) menyatakan bahwa Cloud Computing adalah kumpulan dari beberapa resources yang terintegrasi menjadi satu dan digunakan melalui web. Cloud Computing didasarkan pada teknologi grid computing yang membuat skalabilitas suatu sistem komputasi menjadi sangat besar dengan cara menggabungkan beberapa sumber daya komputer menjadi satu resource. Sehingga seringkali cloud computing disebut juga sebagai grid computing yang digabungkan dengan virtualisasi.

Cloud Computing berkembang sejak tahun enam puluhan bersamaan dengan perkembangan internet dan web. Internet mengalami perkembangan yang lebih cepat sehingga menjadi pendorong berkembangnya teknologi Cloud Computing.

Pada 1999, Salesforce.com menjadi pencetus pertama aplikasi perusahaan yang dijalankan melalui internet kemudian diikuti oleh Amazon Web Services di tahun 2006 yang menggunakan 
teknologi Elastic Compute Cloud (EC2). Teknologi EC2 menyebabkan adanya situs layanan web yang dikomersialkan, sehingga memungkinkan perusahaan kecil / individu untuk menyewa komputer atau server agar dapat menjalankan aplikasi komputer mereka. Di tahun 2009, Google mulai menawarkan aplikasi berbasis browser melalui Google Apps, yang salah satunya adalah Google Docs.

\section{Alasan Penggunaan Cloud Computing}

Beberapa alasan pelaku bisnis menerapkan teknologi Cloud Computing. Alasan pertama adalah Cloud Computing sebagai sebuah model layanan berbasis internet untuk menampung sumber daya sebuah perusahaan yang mana artinya perusahaan tidak perlu lagi memiliki infrastruktur dikarenakan adanya perusahaan yang menyediakan fasilitas penyimpanan di internet.

Alasan berikutnya lebih bersifat ekonomis yaitu melakukan penekanan biaya yang harus dikeluarkan untuk pembelian infrastruktur dan software, dan alasan terakhir adalah perusahaan tidak memerlukan pengetahuan yang mendalam mengenai IT karena sudah didukung oleh perusahaan yang menyediakan layanan penyimpanan.

\section{Karakteristik Cloud Computing}

National Institute of Standards and Technology (NIST, 2011), mengidentifikasikan lima karateristik penting dari Cloud Computing antara lain sebagai berikut: (1) broad network access kemampuan yang tersedia melalui jaringan dan diakses melalui standad mekanisme seperti penggunaan telepon selular, laptop, PDA; (2) on-demand self-service - pengguna dapat memesan dan mengelola layanan tanpa interaksi manusia dengan penyedia layanan, misalnya dengan menggunakan sebuah portal web dan manajemen antar muka. Pengadaan dan perlengkapan layanan serta sumber daya yang terkait menjadi otomatis; (3) rapid elasticity - kemampuan dapat dengan cepat dan elastis ditetapkan; (4) measured service - sistem cloud computing secara otomatis mengawasi dan mengoptimalkan penggunaan sumber-daya dengan memanfaatkan kemampu-an pengukuran (metering) pada beberapa tingkat yang sesuai dengan jenis layanan (misalnya, penyimpanan, pemrosesan, bandwidth, dan account pengguna aktif); (5) resource pooling - penyatuan sumberdaya komputasi yang dimiliki penyedia untuk melayani beberapa konsumen menggunakan model multipenyewa, dengan sumberdaya fisik dan virtual yang berbeda, ditetapkan secara dinamis dan ditugaskan sesuai dengan permintaan konsumen.

\section{Model Penyebaran Cloud Computing}

Model penyebaran Cloud Computing dibagi menjadi empat oleh NIST (2011), yaitu: (1) Hybrid cloud - infrastruktur awan merupakan komposisi dari dua atau lebih awan (swasta, komunitas, atau publik) yang masih entitas unik namun terikat bersama oleh standar atau kepemilikan teknologi yang menggunakan data dan portabilitas aplikasi; (2) public cloud. - infrastruktur awan yang dibuat tersedia untuk umum atau kelompok industri besar dan dimiliki oleh sebuah organisasi yang menjual layanan awan; (3) community cloud - infrastruktur awan digunakan secara bersama oleh beberapa organisasi dan mendukung komunitas tertentu yang telah berbagi concerns (misalnya, misi, persyaratan keamanan, kebijakan, dan pertimbangan kepatuhan); (4) private cloud - infrastruktur awan yang semata-mata dioperasikan bagi suatu organisasi.

\section{Alasan Perusahaan Tidak Dapat Menolak Cloud Computing}

Pada masa kini Cloud Computing memang belum diminati oleh perusahaan-perusahaan, namun seiring berkembangnya bisnis yang didukung dengan internet, atau proses nya dibantu dengan proses internet. Cloud Computing merupakan bagian yang penting bagi bisnis. Kebanyakan ahli IT pada saat ini menyatakan bahwa Cloud Computing merupakan bagian yang paling penting bagi 
industri dan perubahan yang paling revolusioner. Cloud Computing bukanlah sesuatu yang hanya dapat dikendalikan oleh industri-industri tertentu, tidak masalah apapun industri yang dijalani, cloud computing memiliki sesuatu yang ditawarkan seperti perubahan model bisnis dengan membayar fasilitas yang sesuai dengan nilai yang ditawarkan. Beberapa perusahaan besar dan terkenal di dunia sudah memeluk teknologi ini, sebagai contoh nya Amazon, Google dan Microsoft. Semakin banyak perusahaan mengembangkan produk mereka menggunakan Cloud Computing sebagai fondasi mereka. Dalam dunia bisnis, Cloud Computing telah merevolusi bisnis di mana bisnis dilakukan dan memungkinkan model bisnis yang terdesentralisasi di mana komunikasi dan pemrosesan IT semakin meningkat. Dengan komunikasi yang lebih baik dan model desentralisasi, bisnis dapat diperluas ke pasar yang lebih luas dan memudahkan untuk mengirim informasi. Karena Cloud Computing menyediakan bisnis dengan antar muka berbasis web yang mencerminkan informasi yang akurat secara real time.

\section{Keuntungan Cloud Computing Bagi Bisnis}

Ada banyak kelebihan saat menggunakan Cloud Computing untuk perusahaan internasional. Salah satu nya adalah fleksibilitas dari penawarannya. Cloud Computing memungkinkan staff untuk mengakses file dan data yang mereka inginkan baik saat mereka sedang bekerja/di dalam kantor atau sedang di luar kantor. Selama mereka memiliki akses internet, staff dapat mengakses informasi dari rumah, di jalan, dari kantor klien atau bahkan melalui smartphone seperti blackberry atau iphone. Staff juga dapat bekerja secara kolaboratif dengan file dan dokumen, dokumen dapat ditampilkan dan diubah dari beberapa lokasi berbeda. Cloud Computing biasanya lebih murah dan mengurangi insentif tenaga kerja bagi perusahaan. Tidak perlu membeli dan meng-install software yang mahal karena Cloud Computing sudah ter-install secara online dan dapat dijalankan darimana saja menggunakan jaringan internet. Perusahaan dapat lebih fleksibel untuk menentukan anggaran karena perusahaan hanya perlu mengeluarkan biaya yang sesuai dengan kebutuhan perusahaan tersebut. Kelebihan yang mencolok pada penggunaan Cloud Computing bagi perusahaan adalah karena bersifat online, Cloud Computing menawarkan penyimpanan virtual yang tidak terbatas dibandingkan server dan hard-drive yang memiliki batas. Ketika membutuhkan ruang penyimpanan yang lebih besar bukannlah menjadi masalah karena perusahaan hanya perlu mengubah layanan penyimpanan ke batas yang lebih besar namun dengan biaya yang berbeda tentunya. Ada pula beberapa keuntungan lainnya pada penggunaan Cloud Computing seperti:

\section{Efektifitas Biaya}

Perusahaan tidak perlu menginvestasikan uang dan waktu untuk menggunakan server standard yang di mana lebih rumit dibandingkan dengan menggunakan metode Cloud. Biaya pemeliharaannya lebih murah dan lebih menghemat waktu. Biaya untuk menggunakan Cloud Computing lebih ekonomis untuk sumber daya seperti bandwidth dan tenaga. Pengguna Cloud Computing juga dapat menghemat uang dalam pembaharuan software, biaya manajemen, dan biaya penyimpanan data. Untuk membuat manajemen sistem file perusahaan membutuhkan biaya yang besar, server dan perangkat keras yang mahal. Keuntungannya adalah terjaminnya data anda karena penurunan resiko kehilangan data yang disebabkan oleh bencana alam. Keuntungan utama dari cloud computing adalah perusahaan hanya membayar sejumlah ruang dan bandwidth yang perusahaan perlukan saja.

\section{Skala dan Kecepatan}

Dengan menggunakan Cloud Computing tidak diperlukan untuk membeli atau mengatur hardware secara manual. Tergantung dengan kebutuhan pengguna dapat mempercepat dan memperlambat prosesnya. 


\section{Stabilitas dan Kemampuan Sistem yang Handal}

Ini merupakan kunci penting dari layanan cloud computing. Penyedia layanan ini memberikan jaminan dan menunjukan kemampuan sistem dalam menghadapi permasalahan mulai dari data backup, disaster recovery dan hardware yang berkualitas.

\section{Inovasi}

Perusahaan sekarang dapat lebih fokus pada inovasi proses karena mereka tidak perlu mengatur sumber daya secara manual. Cloud Computing menghasilkan pengembangan yang lebih cepat untuk fase percobaan.

\section{Lokasi}

Area dengan pengeluaran tambahan yang rendah dapat menggunakan layanan Cloud ini dan merasakan kelebihannya. Banyak website yang berbeda dapat membantu perusahaan dalam menanggulangi bencana di mana dapat membantu perusahaan dalam mengurangi biaya.

\section{Tidak Terbatas Tempat dan Waktu}

Dengan menggunakan cloud computing, perusahaan dapat mengakses database di manapun dengan perangkat gadget tanpa perlu memikirkan keberadaan server-nya. Di mana dan kapan saja perusahaan dapat mengakses layanan ini. Tanpa disadari semua orang dapat bersama-sama mengakses data pada waktu bersamaan.

\section{Dapat Digunakan Secara Bersamaan}

Tidak hanya efektif dalam masalah biaya, tetapi Cloud Computing memungkinkan akses bersamaan pada satu waktu, sehingga tidak membuang waktu untuk antri dalam mengakses sumber informasi

\section{Ruang Penyimpanan Besar}

Ketika menggunakan Cloud Computing perusahaan akan memiliki ruang penyimpanan yang lebih besar untuk menyimpan file dan data yang ingin mereka simpan.

\section{Resiko Dari Cloud Computing}

Cloud Computing selain memiliki banyak kelebihan juga memiliki resiko, antara lain: (1) user tidak mengetahui secara fisik apa yang terjadi pada data nya, hanya berharap pada tanggung jawab provider; (2) ketika data tersimpan secara eksternal, bencana sulit dihadapi karena hanya mengandalkan provider dalam pemulihan; (3) ketika provider mengalami kepailitan.

\section{Peluang Dan Hambatan Cloud Computing}

Armbrust et al (2010) merangkum daftar peringkat hambatan untuk pertumbuhan cloud computing. Tiga pertama mempengaruhi adopsi, lima berikutnya mempengaruhi pertumbuhan dan dua terakhir adalah kebijakan dan hambatan bisnis. Setiap hambatan dipasangkan dengan peluang untuk mengatasinya, mulai dari pengembangan produk hingga proyek penelitian (Tabel 1). 
Tabel 1 Peluang dan Hambatan Cloud Computing (Armbrust et al, 2010)

\begin{tabular}{ll} 
Obstacle & Opportunity \\
\hline $\mathbf{1}$ Availability/Business Continuity & Use Multiple Cloud Providers \\
\hline $\mathbf{2}$ Data Lock-In & $\begin{array}{l}\text { Standardize APIs; Compatible SW to enable Surge } \\
\text { or Hybird Cloud Computing }\end{array}$ \\
\hline $\mathbf{3}$ Data Confidentiality and Auditability & Deploy Encryption, VLANs, Firewalls \\
\hline $\mathbf{4}$ Data Transfer Bottlenecks & FedExing Disks; Higher BW Switches \\
\hline $\mathbf{5}$ Performance Unpredictability & $\begin{array}{l}\text { Improved VM Support; Flash Memory; } \\
\text { Gang Schedule VMs }\end{array}$ \\
\hline $\mathbf{6}$ Scalable Storage & Invent Scalable Store \\
\hline $\mathbf{7}$ Bugs in Large Distributed Systems & $\begin{array}{l}\text { Invent Debugger that relies } \\
\text { on Distributed VMs }\end{array}$ \\
\hline $\mathbf{9}$ Reputation Fate Sharing & $\begin{array}{l}\text { Invent Auto-Scaler that relies on ML; Snapshots } \\
\text { for Conservation }\end{array}$ \\
\hline $\mathbf{1 0}$ Software Licensing & Offer reputation-guarding services like those for email \\
\hline
\end{tabular}

\section{Business Continuity and Service Availability}

Organisasi merasa khawatir apakah utilitas layanan komputasi akan memiliki ketersediaan yang memadai, hal ini membuat beberapa organisasi mulai berhati-hati terhadap cloud computing. Vendor cloud computing bisa menawarkan hardware dan software agar dapat memberikan keandalan yang lebih tinggi, mungkin dengan harga tinggi. Keandalan ini kemudian bisa dijual kepada pengguna sebagai service level agreement.

Bahkan jika perusahaan memiliki beberapa pusat data di daerah yang berbeda dengan menggunakan network provider yang berbeda, mungkin memiliki infrastruktur perangkat lunak umum dan sistem akuntansi, atau perusahaan bahkan mungkin keluar dari bisnis. Pelanggan besar akan enggan untuk bermigrasi ke cloud computing tanpa strategi kelangsungan bisnis untuk situasi seperti itu.

Sama seperti penyedia layanan internet besar menggunakan penyedia jaringan ganda sehingga kegagalan oleh sebuah perusahaan tidak akan membuat mereka berhenti dan satu-satunya solusi yang masuk akal untuk ketersediaan yang sangat tinggi sesungguhnya adalah beberapa cloud computing provider.

\section{Data Lock-In}

Software stacks telah meningkatkan interoperabilitas antara platform, tetapi penyimpanan API (Application Programming Interface) untuk cloud computing masih memiliki hak patennya, atau setidaknya belum menjadi subyek standarisasi aktif. Dengan demikian, pelanggan tidak bisa dengan mudah mengambil data dan program dari satu situs ke situs yang lain. Kekhawatiran atas kesulitan pengambilan data dari cloud mencegah beberapa organisasi untuk mengadopsi cloud computing. Mengunci pelanggan mungkin menarik bagi cloud computing provider, tetapi pengguna mereka rentan terhadap kenaikan harga, masalah keandalan, atau bahkan untuk provider yang akan keluar dari bisnis. 
Salah satu solusinya adalah dengan standarisasi API sedemikian rupa sehingga pengembang SaaS (Software as a Service) bisa menyebarkan layanan dan data di seluruh cloud computing provider sehingga kegagalan satu perusahaan tidak akan mengambil semua data pelanggan.

\section{Data Confidentiality and Auditability}

Meskipun organisasi telah banyak menggunakan perusahaan outsourcing serta menggunakan layanan email eksternal untuk menyimpan informasi sensitif, keamanan adalah salah satu keberatan yang paling sering diajukan untuk cloud computing, para analis dan perusahaan yang skeptis menanyakan "siapa yang dapat mempercayai data penting mereka di luar sana?" juga termasuk masalah auditability dan peraturan yang harus disediakan untuk data perusahaan dapat dipindahkan ke cloud.

Pengguna Cloud menghadapi ancaman keamanan dari luar dan dalam cloud. Banyak masalah keamanan yang terlibat dalam melindungi cloud dari ancaman luar seperti sudah menghadapi pusat data yang besar. Di dalam Cloud, tanggung jawab dibagi antara pihak-pihak, termasuk pengguna cloud, cloud vendor, dan setiap vendor pihak ketiga.

Pengguna cloud bertanggung jawab untuk keamanan pada tingkat aplikasi. Cloud Provider bertanggung jawab atas keamanan fisik, dan menegakkan kebijakan firewall eksternal. Keamanan untuk lapisan menengah software stack dibagi antara pengguna dan operator, semakin rendah tingkat abstraksi pengguna, semakin banyak tanggung jawab yang menyertainya.

Mekanisme keamanan utama dalam cloud saat ini adalah virtualisasi. Ini adalah pertahanan yang kuat, dan melindungi terhadap upaya pengguna saling menyerang satu sama lain. Namun, tidak semua sumber daya virtualisasi dan tidak semua lingkungan virtualisasi yang bebas bug. Software virtualisasi telah diketahui mengandung bug yang memungkinkan kode virtual untuk "membebaskan diri" sampai batas tertentu. Virtualisasi jaringan yang tidak benar dapat memungkinkan pengguna kode akses ke bagian sensitif dari penyedia infrastruktur, atau ke sumber daya pengguna lain. Tantangan-tantangan ini, meskipun mirip dengan mereka yang terlibat dalam mengelola pusat data besar non-cloud, di mana aplikasi yang berbeda perlu dilindungi satu sama lain. Setiap layanan Internet besar perlu memastikan bahwa lubang keamanan tidak membahayakan segala sesuatu yang lain.

Masalah keamanan adalah masalah non-cloud juga. Yang menjadi pertahanan standar berupa enkripsi level pengguna, hal tersebut juga efektif dalam cloud. Auditability dapat ditambahkan sebagai lapisan tambahan di luar jangkauan OS virtual, menyediakan fasilitas yang dapat dikatakan lebih aman daripada yang dibangun pada aplikasi itu sendiri dan tanggung jawab sentralisasi software yang berkaitan dengan kerahasiaan dan auditability menjadi lapisan logis tunggal. Seperti fitur baru memperkuat perspektif cloud computing mengubah fokus dari spesifik hardware menjadi kemampuan virtual.

\section{Data Transfer Bottlenecks}

Aplikasi terus berkembang menjadi lebih berfokus pada data. Jika kita mengasumsikan aplikasi dapat "pulled apart" melintasi batas-batas cloud, hal ini dapat mempersulit penempatan data dan delivery. Dengan biaya trasfer data sebesar Rp. 900.000,- sampai Rp. 1.500.000,- per terabyte, biaya-biaya tersebut dapat dengan cepat membuat biaya transfer data menjadi masalah penting. Pengguna Cloud dan cloud provider harus berpikir tentang implikasi penempatan dan lalu lintas pengiriman data pada setiap tingkat sistem jika ingin meminimalkan biaya. Alasan seperti ini menjadi pertimbangan dalam pengembangan layanan CloudFront baru dari Amazon. 
Satu peluang untuk mengatasi tingginya biaya transfer internet adalah dengan mengirimkan disk. Cara termurah untuk mengirim banyak data adalah dengan mengirimkan disk atau bahkan seluruh komputer. Walaupun cara ini tidak mengatasi setiap kasus namun secara efektif menangani kasus delay-tolerant point-to-point transfer, seperti mengimpor kumpulan data yang besar.

\section{Performance Unpredictability}

Mesin virtual (VM) dapat berbagi CPU dan memori sangat baik dalam cloud computing, tetapi berbagi jaringan dan disk I/O lebih bermasalah. Armburst mengukur 75 kasus menjalankan benchmark memori STREAM. Bandwidth rata-rata adalah $1.355 \mathrm{MB} /$ detik, dengan standar deviasi di seluruh kasus hanya $52 \mathrm{MB} /$ detik, kurang dari $4 \%$ dari rata-rata. Bandwidth disk juga diukur untuk rata-rata 75 kasus setiap file 1GB menulis ke lokal disk. Bandwidth menulis disk hampir 55MB per detik dengan standar deviasi $9 \mathrm{MB} /$ detik, atau sekitar $16 \%$ dari rata-rata. Ini menunjukkan masalah gangguan $\mathrm{I} / \mathrm{O}$ antara mesin virtual.

Salah satu peluang adalah dengan meningkatkan arsitektur dan sistem operasi untuk efisiensi virtualisasi interupsi dan I/O channel. IBM mainframe dan sistem operasi sebagian besar mengatasi masalah ini pada 1980-an, sehingga kita memiliki contoh sukses yang dapat dipelajari.

Kemungkinan lain adalah memori flash akan mengurangi gangguan I/O. Flash adalah memori semikonduktor yang melindungi informasi ketika dimatikan seperti hard disk mekanik, tapi karena tidak memiliki bagian yang bergerak, jauh lebih cepat untuk mengakses (mikrodetik vs milidetik) dan menggunakan energi lebih sedikit. Flash memory dapat mempertahankan lebih banyak I/O per detik per GB penyimpanan dari disk hingga beberapa mesin virtual yang bertentangan dengan beban kerja I/O bisa hidup berdampingan yang lebih baik pada komputer fisik yang sama tanpa campur tangan kita lihat dengan disk mekanik.

\section{Scalable Storage}

Ada tiga hal yang menjadi daya tarik cloud computing yaitu penggunaan jangka pendek, tidak ada biaya dimuka, dan kapasitas tak terbatas sesuai permintaan. Sementara itu apa yang terjadi bila diterapkan pada perhitungan, hal itu masih kurang jelas untuk diterapkan pada penyimpanan yang kuat. Ada banyak usaha untuk menjawab hal ini, variasi dalam query dan penyimpanan API, jaminan kinerja yang ditawarkan, dan semantik konsistensi yang dihasilkan. Yang menjadi peluang, apa yang masih merupakan masalah penelitian, adalah untuk menciptakan sebuah sistem penyimpanan yang tidak hanya memenuhi harapan programmer yang ada dalam hal ketahanan, ketersediaan tinggi, dan kemampuan untuk mengelola dan query data, tetapi menggabungkannya dengan keunggulan cloud.

\section{Bugs in Large Distributed Systems}

Salah satu tantangan yang sulit dalam cloud computing adalah menghapus kesalahan dalam skala sistem terdistribusi yang sangat besar. Hal umum yang sering terjadi adalah bahwa 'bug' ini tidak bisa direproduksi dalam konfigurasi yang lebih kecil, sehingga debugging harus terjadi pada pusat data produksi.

\section{Scaling Quickly}

Dalam storage dan bandwidth jaringan berlaku sistem Pay-as-you-go, termasuk menghitung byte yang digunakan. Perhitungan ini sedikit berbeda, tergantung pada tingkat virtualisasi. Kesempatan ini kemudian secara otomatis menanggapi secara cepat naik dan turun beban untuk menghemat uang, tetapi tanpa melanggar service level aggreement. Alasan lain untuk scaling adalah untuk melestarikan sumber daya selayaknya uang. Karena komputer idle menggunakan sekitar duapertiga dari kekuatan komputer disaat sibuk, sehingga perlu hati-hati menggunakan sumber daya yang 
mampu mengurangi dampak dari pusat data pada lingkungan. Penyedia layanan cloud computing sudah melakukan perhitungan yang hati-hati dan biaya overhead yang rendah dari konsumsi sumber daya. Dengan memaksakan biaya minimal, utilitas komputasi mendorong programmer untuk memperhatikan efisiensi.

\section{Reputation Fate Sharing}

Perilaku buruk salah satu pelanggan dapat mempengaruhi reputasi orang lain yang menggunakan cloud computing yang sama. Misalnya, daftar hitam dari IP addresses EC2 oleh layanan pencegahan spam mungkin dapat membatasi aplikasi. Masalah legal lainnya adalah pertanyaan tentang pengalihan tanggung jawab hukum - penyedia layanan cloud computing ingin pelanggan harus bertanggung jawab seperti misalnya, perusahaan mengirim spam harus dianggap bertanggung jawab, bukan tanggungjawab Amazon.

\section{Software Licensing}

Lisensi software saat ini biasanya membatasi komputer pada saat perangkat lunak dijalankan. Pengguna membayar software dan membayar biaya pemeliharaan tahunan. Memang, SAP mengatakan bahwa akan meningkatkan biaya pemeliharaan yang tahunan untuk setidaknya 22\% dari harga pembelian software, yang dekat dengan harga Oracle. Karenanya, banyak penyedia layanan cloud computing awalnya bergantung pada open source software karena model lisensi untuk software komersial tidak cocok untuk utilitas komputasi.

\section{PENUTUP}

Cloud Computing saat ini secara perlahan sudah menjadi tren yang di pakai oleh perusahaan maupun perorangan. Dengan biaya yang relatif murah dan fasilitas yang memberikan nilai lebih bagi penggunanya Cloud Computing menjadi semakin diminati. Cloud Computing merupakan teknologi yang harus dipertimbangkan oleh perusahaan-perusahaan baik kecil, menengah atau besar. Biasa nya perusahaan besar memiliki kebutuhan penyimpanan yang besar dikarenakan data dan file yang sangat banyak. Dengan Cloud Computing masalah penyimpanan sudah bukanlah menjadi masalah. Perusahaan sudah tidak perlu mengembangkan server dan kapasitas penyimpanan dengan biaya yang besar, dengan Cloud Computing biaya dalam pemeliharaan dan penyimpanan data dan file semakin murah.

\section{DAFTAR PUSTAKA}

Al Azhar, Muhammad Fahmi. (2013). Pengertian Cloud Computing dan Perkembangannya. Diakses 19 Maret 2013 dari http://azuharu.net/grid-computing/pengertian-cloud-computing-danperkembangannya/.

Armbrust, M., Fox, A., Griffith, R,. Joseph, Anthony D., Katz, R., Konwinski, A., Gunho Lee, Patterson, D., Rabkin, A., Stoica, I., Zaharia, M. (2010). A View of Cloud Computing. Communication of The ACM, 53(4).

National Institute of Science and Technology. (2011). The NIST Definition of Cloud Computing. 